\title{
ANALISIS KEMAMPUAN KOMUNIKASI MATEMATIS SISWA SMP PADA MATERI SEGITIGA DAN SEGIEMPAT
}

\author{
Agus Dwi Wijayanto ${ }^{1}$, Siti Nurul Fajriah ${ }^{2}$, Ika Wahyu Anita ${ }^{3}$ \\ ${ }^{1}$ IKIP Siliwangi Bandung, Jl, Terusan Jenderal Sudirman Cimahi \\ ${ }^{2}$ IKIP Siliwangi Bandung, Jl, Terusan Jenderal Sudirman Cimahi \\ ${ }^{3}$ IKIP Siliwangi Bandung, Jl, Terusan Jenderal Sudirman Cimahi \\ Email penulis pertama: agusdwi1919@yahoo.co.id
}

\begin{abstract}
This study aims to analyze the mathematical communication skills of junior high school students in triangular and rectangular materials. With the sample of research is 5 students of class VII which is taken at random in one of junior high school in Cimahi city. The type of research used is descriptive qualitative research. The instrument used is a test of mathematical communication skills in the form of 5 items essay-shaped question. The test results that have been done on some mathematical communication ability problems still show below average results. Then it can be concluded that the level of students' mathematical communication ability is still relatively low.
\end{abstract}

Keywords: Mathematical Communication Skill, Triangle and Quadrilateral

\begin{abstract}
Abstrak
Penelitian ini bertujuan untuk menganalisis kemampuan komunikasi matematis siswa SMP pada materi segitiga dan segiempat. Dengan sampel penelitian adalah 5 orang siswa kelas VII yang diambil secara acak di salah satu SMP di kota Cimahi. Jenis penelitian yang digunakan adalah penelitian deskriptif kualitatif. Adapun instrumen yang digunakan adalah soal tes kemampuan komunikasi matematis berupa 5 butir soal berbentuk essay. Adapun hasil tes yang telah dilakukan pada beberapa soal kemampuan komunikasi matematis masih menunjukkan hasil dibawah rata-rata. Maka dapat disimpulkan bahwa tingkat kemampuan komunikasi matematis siswa masih tergolong rendah.
\end{abstract}

Kata kunci: Kemampuan Komunikasi Matematis, Segitiga dan Segiempat

Komunikasi secara umum dapat diartikan sebagai suatu cara untuk menyampaikan suatu pesan dari pembawa pesan ke penerima pesan untuk memberitahu, pendapat, atau perilaku baik langsung secara lisan maupun tak langsung melalui media. Salah satu bentuk Komunikasi matematis adalah kegiatan memahami matematika. Memahami matematika memiliki peran sentral dalam pembelajaran matematika, sebab kegiatan memahami mendorong peserta didik belajar bermakna secara aktif. Komunikasi di dalam kelas terjadi antara guru dan siswa, dimana cara pengalihan pesannya dapat secara lisan maupun tertulis.

Dalam berkomunikasi harus dipikirkan bagaimana caranya agar pesan yang disampaikan seseorang itu dapat dipahami oleh orang lain. Untuk mengembangkan kemampuan berkomunikasi, dapat disampaikan dengan berbagai bahasa salah satumya bahasa matematis. Salah satu tujuan pembelajaran matematika di sekolah adalah agar siswa memiliki kemampuan mengkomunikasikan gagasan dengan simbol, tabel, diagram, atau media lain untuk memperjelas keadaan atau masalah (Depdiknas, 2006). Selain itu, komunikasi merupakan salah satu pengalaman belajar yang harus dialami siswa dalam proses pembelajaran pada setiap mata pelajaran (Permendikbud Nomor 81A, 2013). Oleh karena itu, kemampuan Komunikasi matematis merupakan hal yang sangat penting dalam 
pembelajaran matematika dan salah satu kompetensi yang harus dimiliki siswa.

Sebagaimana Asikin mengungkapkan pentingnya kemampuan Komunikasi matematis dalam pembelajaran matematika yaitu untuk membantu siswa menajamkan cara siswa berpikir, sebagai alat untuk menilai pemahaman siswa, membantu siswa membangun pengetahuan matematiknya, meningkatkan kemampuan pemecahan masalah matematik, memajukan penalarannya, membangun kemampuan diri, meningkatkan keterampilan sosialnya, serta bermanfaat dalam mendirikan komunitas matematik (Hendriana \& Sumarmo, 2014:30)

Adapun indikator kemampuan Komunikasi matematis siswa yang dikemukakan oleh Soemarmo (Hendriana, Rochaeti \& Sumarmo, 2017:62), antara lain:

1. Menyatakan benda-benda nyata, situasi dan peristiwa sehari-hari ke dalam bentuk model matematika (gambar, tabel, diagram, grafik, ekspresi aljabar);

2. Menjelaskan ide, dan model matematika (gambar, tabel, diagram, grafik, ekspresi aljabar) ke dalam bahasa biasa;

3. Menjelaskan dan membuat pertanyaan matematika yang dipelajari;

4. Mendengarkan, berdiskusi dan menulis tentang matematika;

5. Membaca dengan pemahman suatu prestasi tertulis; dan

6. Membuat konjektur, menyusun argumen, merumuskan definisi dan generalisasi.

Berdasarkan hasil observasi di lapangan dan wawancara dengan guru matematika di salah satu SMP di Kota Cimahi, diperoleh hasil bahwa kemampuan Komunikasi matematis siswa masih tergolong rendah, siswa cenderung mengalami kesulitan dan melakukan kesalahan saat menyatakan permasalahan pada soal ke dalam notasi dan simbol matematika. Dilihat dari hasil Ulangan Harian Siswa pada materi Segitiga dan Segiempat di kelas VII, ditemukan bahwa masih rendahnya tingkat kemampuan siswa dalam memahami dan menyatakan situasi ke dalam bahasa matematika.

Kemampuan berkomunikasi dalam pembelajaran matematika di sekolah menengah pertama kurang mendapat perhatian dari para guru. Disebabkan guru masih cenderung aktif, dengan pendekatan ceramah menyampaikan materi pada para peserta didik. Sehingga kemampuan Komunikasi matematis siswa lemah. Siswa kurang dapat mengkomunikasikan ide-ide matematisnya secara jelas dan benar, baik secara lisan maupun tulisan. Maka dari itu diperlukan sistem pembelajaran yang baik untuk menghasilkan kualitas belajar yang baik pula. Sesuai dengan yang diungkapkan Djemari Mardapi bahwa usaha dalam meningkatkan kualitas pendidikan dapat ditempuh melalui peningkatan kualitas pembelajaran dan sistem penilaian (Fitrianna \& Anita, 2017).

Berdasarkan paparan di atas, maka permasalahan yang akan dibahas adalah analisis indikator kemampuan komunikasi matematis siswa pada materi segitiga dan segiempat. Sejalan dengan itu, 
maka tujuan dari penelitian ini adalah untuk menganalisis dan mendeskripsikan kemampuan Komunikasi matematis siswa SMP pada materi Segitiga dan Segiempat.

\section{METODE}

Jenis penelitian yang digunakan adalah penelitian deskriptif kualitatif. Penelitian dengan menggunakan metode ini bertujuan untuk menggambarkan kondisi yang terjadi pada saat penelitian berlangsung. Penelitian ini ditulis untuk menganalisis dan mendeskripsikan kemampuan Komunikasi matematis siswa SMP pada materi Segitiga dan Segiempat. Adapun subjek penelitian ini adalah 5 orang siswa kelas VII yang diambil secara acak di salah satu SMP di Kota Cimahi. Instrumen yang digunakan adalah soal tes kemampuan Komunikasi matematis berupa 5 butir soal berbentuk essay.

Teknik pengolahan data terhadap skor kemampuan Komunikasi matematis siswa menurut Sumarmo (2016:2).

Tabel 1

Pedoman Penskoran Kemampuan Komunikasi Matematis

\begin{tabular}{|c|c|}
\hline Skor & Kriteria \\
\hline 4 & $\begin{array}{l}\text { Respons lengkap dan jelas, tidak ragu-ragu,diagram lengkap, komunikasi efisien, sajian } \\
\text { logis, disertai dengan contoh. }\end{array}$ \\
\hline 3 & $\begin{array}{l}\text { Respons benar, lengkap dan jelas, diagram lengkap, komunikasi efisien, dan sajian } \\
\text { lengkap tapi tidak disertai contoh. }\end{array}$ \\
\hline 2 & $\begin{array}{l}\text { Respons benar, lengkap dan jelas, diagram lengkap, komunikasi dan sajian kurang } \\
\text { lengkap dan tidak disertai contoh. }\end{array}$ \\
\hline 1 & $\begin{array}{c}\text { Respons benar tapi kurang lengkap/ jelas, diagram, komunikasi dan sajian kurang } \\
\text { lengkap, tidak disertai contoh tidak ada. }\end{array}$ \\
\hline 0 & $\begin{array}{c}\text { Respons, komunikasi tidak efisien, misinterpretasi (tidak ada jawaban apapun/lembar } \\
\text { jawaban siswa kosong) }\end{array}$ \\
\hline
\end{tabular}

Tabel 2

Kategori Pencapaian Kemampuan Komunikasi Matematis Siswa

\begin{tabular}{|c|c|}
\hline Pencapaian Kemampuan Komunikasi Matematis & Kategori \\
\hline$\leq 33 \%$ & Rendah \\
\hline$>33 \%$ & Sedang \\
\hline$>66 \%$ & Tinggi \\
\hline
\end{tabular}

Jadi berdasarkan acuan tersebut peneliti memberikan penilaian terhadap hasil kegiatan siswa, sehingga penilaian terhadap hasil kerja siswa dapat diukur dengan baik. 


\section{HASIL DAN PEMBAHASAN}

Peneliti memberikan tes kepada 5 orang siswa kelas VII di salah satu SMP di Kota Cimahi dengan tingkat kemampuan siswa yang berbeda-beda. Adapun hasil yang diperoleh adalah:

Tabel 3

Presentase Kemampuan Komunikasi Matematis

\begin{tabular}{|c|c|c|c|c|c|}
\hline \multirow{2}{*}{ Kode siswa } & \multicolumn{5}{|c|}{ Skor } \\
\cline { 2 - 6 } & Soal no 1 & Soal no 2 & Soal no 3 & Soal no 4 & Soal no 5 \\
\hline 001 & 2 & 1 & 0 & 0 & 0 \\
\hline 002 & 2 & 3 & 2 & 1 & 0 \\
\hline 003 & 2 & 1 & 2 & 3 & 0 \\
\hline 004 & 3 & 3 & 2 & 1 & 1 \\
\hline 005 & 3 & 3 & 2 & 1 & 0 \\
\hline Total skor butir soal & 12 & 11 & 8 & 6 & 1 \\
\hline $\begin{array}{c}\text { Banyak siswa x skor } \\
\text { maksimal }\end{array}$ & 20 & 20 & 20 & 20 & 20 \\
\hline Presentase butir soal & $60 \%$ & $55 \%$ & $40 \%$ & $30 \%$ & $5 \%$ \\
\hline
\end{tabular}

Berdasarkan tabel di atas menunjukkan perolehan skor terhadap kemampuan Komunikasi matematis siswa. Dapat dilihat bahwa soal no. 1 dengan presentase $60 \%$ untuk indikator menyatakan benda nyata dalam bentuk matematika. Soal no. 2 dengan presentase $55 \%$ untuk indikator menyatakan peristiwa sehari-hari dalam bahasa matematika. Soal no. 3 dengan presentase $40 \%$ untuk indikator menjelaskan dan membuat pertanyaan matematika yang dipelajari. Soal no. 4 dengan presentase $30 \%$ untuk indikator membuat konjektur, menyusun argumen, merumuskan definisi dan generalisasi. Soal no. 5 dengan presentase $5 \%$ untuk indikator mengungkapkan kembali suatu uraian paragraf matematika dalam bahasa sendiri.

Berikut ini adalah tampilan soal dan jawaban siswa yang mengalami kesalahan.

Soal no. 1

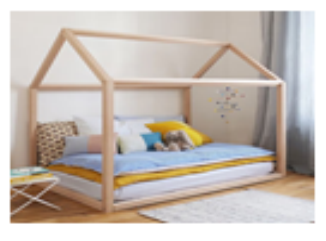

Dari gambar disamping, terdapat kerangka rumahrumahan milik Sinta. Dapatkah kamu menyebutkan dan menjelaskan bagun datar apa sajakah yang terdapat pada kerangka tersebut!

Gambar 1. Soal No. 1

Soal no. 1 siswa diminta untuk menyebutkan dan menjelaskan bangun datar yang terdapat dalam gambar. Dapat kita lihat bahwa presentasenya adalah 60\%. Dibawah ini adalah contoh hasil pekerjaan siswa yang mengalami kesalahan dalam pengerjaannya. 


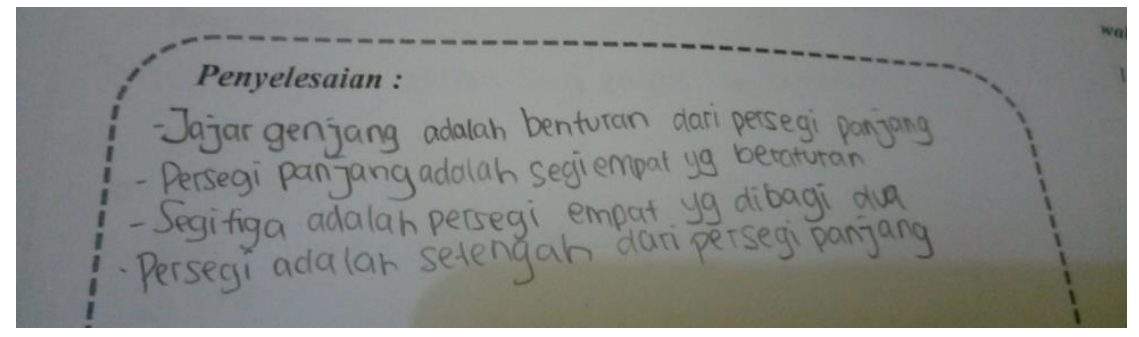

Gambar 2. Jawaban Soal No. 1

Siswa sudah dapat menyebutkan berbagai macam bangun datar segitiga segiempat tetapi siswa belum dapat mendefinisikannya secara jelas.

Soal no. 2

Sepetak sawah milik Pak Anwar berbentuk jajargenjang yang memiliki panjang $18 \mathrm{~m}$
dan $9,5 \mathrm{~m}$. Disekeliling sawah itu, akan di pasang pagar dengan biaya Rp. $135.000 / \mathrm{m}$
Berapakah biaya yang diperlukan untuk pemasangan pagar tersebut!

Gambar 3. Soal No. 2

Soal no. 2 siswa diminta untuk menghitung biaya pemasangan pagar. Dapat kita lihat bahwa presentasenya adalah 55\%. Dibawah ini adalah contoh hasil pekerjaan siswa yang yang mengalami kesalahan dalam pengerjaannya.

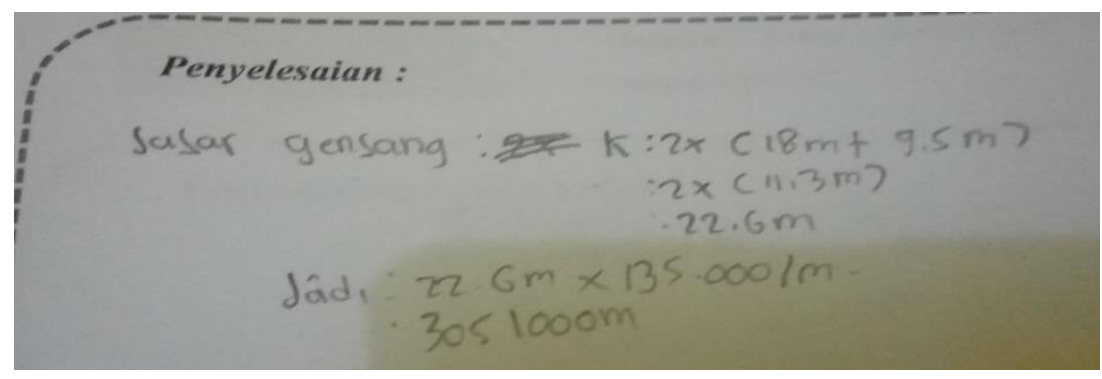

Gambar 4. Jawaban Soal No. 2

Siswa tidak menyebutkan unsur-unsur apa saja yang diketahui berdasarkan soal, tetapi berdasarkan jawaban tersebut peneliti menilai siswa sudah memahami soal.

Soal no. 3

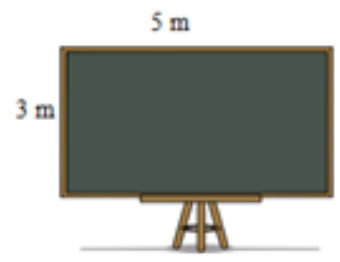

Perhatikan gambar disamping!

Definisikanlah bangun datar diatas dan Buatlah dua pertanyaan matematika yang berkaitan dengan gambar tersebut berikut jawabannya!

Gambar 5. Soal No. 3 
Soal no. 3 siswa diminta untuk mendifinisikan bangun datar yang terdapat dalam gambar dan membuat 2 pertanyaan. Dapat kita lihat bahwa presentasenya adalah 40\%. Dibawah ini adalah contoh hasil pekerjaan siswa yang yang mengalami kesalahan dalam pengerjaannya.

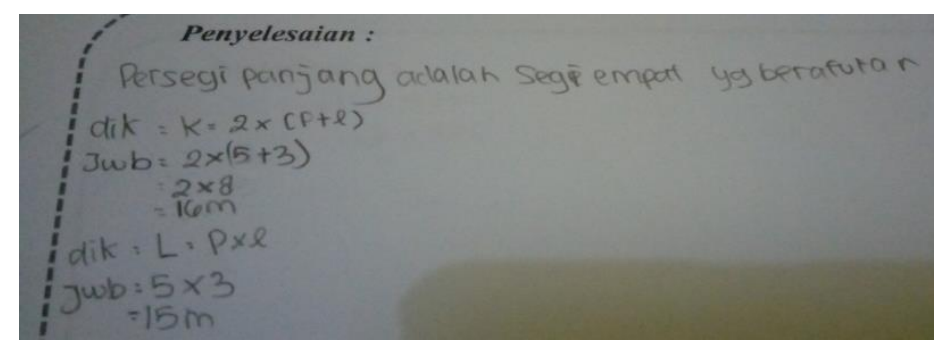

Gambar 6. Jawaban Soal No. 3

Siswa belum dapat mendefinisikan secara jelas bangun datar yang dimaksud, dan siswa dinilai masih mengalami kesulitan untuk membuat soal.

Soal no. 4

Perhatikan gambar berikut di bawah ini!

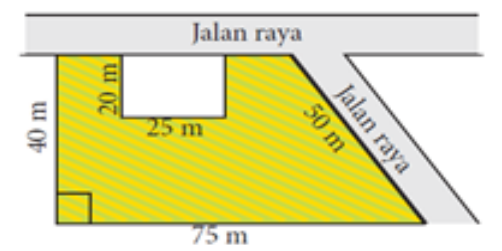

Daerah yang diarsir adalah area tanah yang ditanami rumput.

Dapatkah kamu menentukan luas hamparan rumput tersebut?

Gambar 7. Soal No. 4

Soal no. 4 siswa diminta untuk menghitung luas daerah yang diarsir yang terdapat dalam gambar. Dapat kita lihat bahwa presentasenya adalah 30\%. Dibawah ini adalah contoh hasil pekerjaan siswa yang yang mengalami kesalahan dalam pengerjaannya.

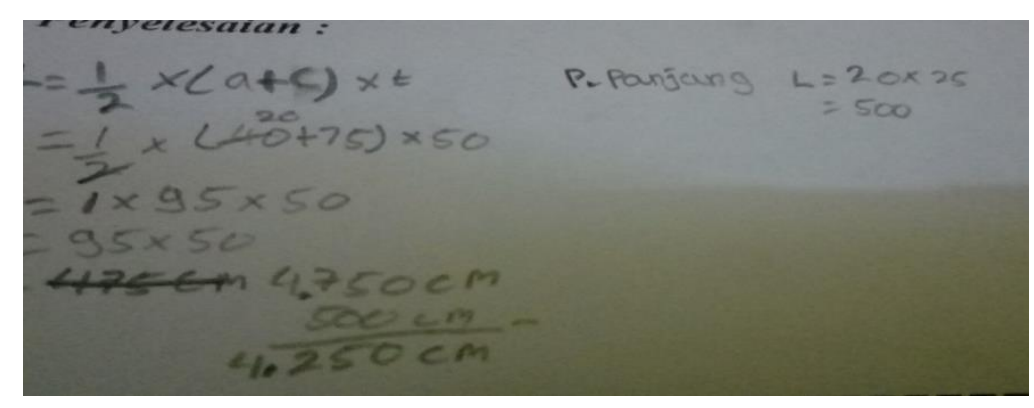

Gambar 8. Jawaban Soal No. 4

Jawaban siswa masih perlu diperbaiki dan siswa perlu mengingat kembali rumus-rumus bangun datar segi empat dan teorema phytagoras. 
Soal no. 5

Sindi akan membuat suatu bangun datar yang memiliki panjang sisi $(3 \mathrm{x}) \mathrm{cm},(12-\mathrm{x})$
$\mathrm{cm},(2 \mathrm{x}+3) \mathrm{cm}$ dengan keliling $27 \mathrm{~cm}$. Tentukan nilai $\mathrm{x}$ dan panjang tiap sisinyad
kemudian gambarlah dan jelaskan bangun datar apa yang Sindi buat?

Gambar 9. Soal No. 5

Soal no. 5 siswa diminta untuk mencari nilai $\mathrm{x}$ dan mensketsakan bangun datar yang diinginkan. Dapat kita lihat bahwa presentasenya adalah 5\%. Dibawah ini adalah contoh hasil pekerjaan siswa yang yang mengalami kesalahan dalam pengerjaannya.

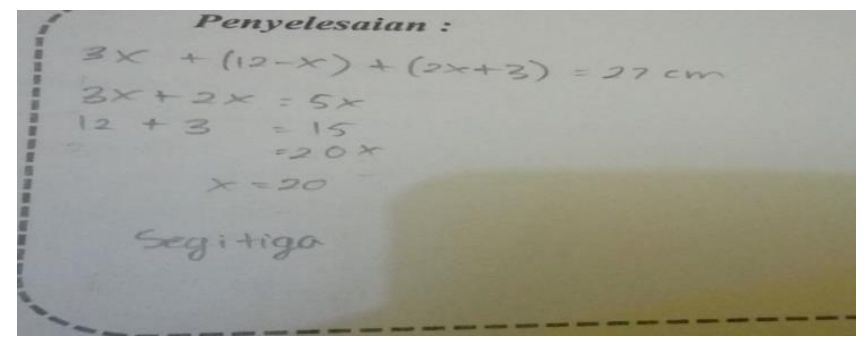

Gambar 10. Jawaban Soal No. 5

Siswa masih terlihat kesulitan untuk mengerjakan soal tersebut, sehingga siswa perlu memahami soal terlebih dahulu.

Berdasarkan deskripsi dan hasil analisis penelitian yang telah dilakukan pada 5 orang siswa kelas VII di salah satu SMP di Kota Cimahi dalam menyelesaikan soal-soal kemampuan Komunikasi matematis siswa masih tergolong rendah. Karena jika kita lihat presentase dari hasil analisis butir soal dapat kita lihat untuk soal no. $160 \%$ dengan indikator menyatakan benda nyata ke dalam bentuk matematika, soal no. $255 \%$ dengan indikator menyatakan peristiwa sehari-hari dalam bahasa atau simbol matematika, soal no. $340 \%$ dengan indikator menjelaskan dan membuat pertanyaan matematika yang dipelajari, soal no. 4 30\% dengan indikator membuat konjektur, menyusun argumen, merumuskan definisi dan generalisasi dan soal no. 5 5\% dengan indikator mengungkapkan kembali suatu uraian paragraf matematika dalam bahasa sendiri.

\section{KESIMPULAN}

Berdasarkan hasil penelitian dan pembahasan yang telah diuraikan, maka dapat diambil kesimpulan sebagai berikut:

1. Kemamapuan Komunikasi matematis siswa SMP pada materi Segitiga dan Segiempat masih termasuk kategori rendah. Hal ini dapat dilihat dari hasil soal-soal yang diujikan terdapat dua 
butir soal dari dua indikator kemampuan komunikasi matematis yang masih berada pada skala $\leq 33 \%$.

2. Siswa kesulitan dalam menyelesaikan soal no. 4 dan no. 5 yang berarti indikator membuat konjektur, menyusun argumen, merumuskan definisi dan generalisasi, serta mengungkapkan kembali suatu uraan paragraf matematika dalam bahasa sendiri masih tergolong rendah.

Dari hasil penelitian ini maka penulis akan melakukan penelitian lebih lanjut terkait kemampuan komunikasi matematis agar kemampuan siswa dapat meningkat.

\section{DAFTAR PUSTAKA}

Astuti, A. (2016). Pengaruh Model Pembelajaran Kooperatif Tipe Two Stay Two Stray (Tsts) Terhadap Hasil Belajar Matematika Siswa Kelas Vii Smp Negeri 2 Bangkinang Kota. Jurnal Cendekia : Jurnal Pendidikan Matematika, (2), 11-28. Retrieved From Http://Journal.Stkiptam.Ac.Id/Index.Php/Cendekia/Article/View/626

Depdiknas. (2006). Kurikulum Tingkat Satuan Pendidikan 2006. Jakarta: Badan Standar Nasional Pendidikan

Fitrianna, A. Y. \& Anita, I. W. (2017). Pengembangan LKS Berbasis Assessment for Learning (AFL) Teman Sejawat untuk Kemampuan Matematis Siswa SMP. Jurnal Edumath. 3 (2), 101-109.

Hendriana, H. Rochaeti, E. E. Sumarmo, U. (2017). Hard Skills dan Soft Skills Matematik Siswa. Bandung: Refika Aditama

Hendriana \& Sumarmo. (2014). Penilaian Pembelajaran Matematika. Bandung: Refika Aditama

Peraturan Menteri Pendidikan dan Kebudayaan Republik Indonesia Nomor 81A Tahun 2013 tentang Implementasi Kurikulum. (2013). Jakarta: Kemendikbud

Sumarmo, U. (2016). Pedoman Pemberian Skor pada Beragam Tes Kemampuan Matematik Bahan Ajar Mata Kuliah Evaluasi Pembelajaran Matematika pada Program Magister Pendidikan Matematika STKIP Siliawangi.

Zulfah, Z. (2017). Analisis Kesalahan Peserta Didik Pada Materi Persamaan Linear Dua Variabel Di Kelas Viii Mts Negeri Sungai Tonang. Jurnal Cendekia : Jurnal Pendidikan Matematika, 1(1), 1-5. Retrieved From Http://Journal.Stkiptam.Ac.Id/Index.Php/Cendekia/Article/View/90

Zulfah, Z. (2017). Tahap Preliminary Research Pengembangan Lkpd Berbasis Pbl Untuk Materi Matematika Semester 1 Kelas Viii Smp. Jurnal Cendekia : Jurnal Pendidikan Matematika, 1(2), 1-12.

Retrieved From Http://Journal.Stkiptam.Ac.Id/Index.Php/Cendekia/Article/View/184 